\title{
Effects of the dietary protein content and the feeding level on protein and energy metabolism in Iberian pigs growing from 50 to $100 \mathrm{~kg}$ body weight
}

\author{
R. Barea, R. Nieto and J. F. Aguilera ${ }^{\dagger}$ \\ Unidad de Nutrición Animal, Estación Experimental del Zaidín (CSIC), Camino del Jueves s/n, 18100 Armilla, Granada, Spain
}

(Received 27 June 2006; Accepted 23 November 2006)

Nutritional requirements of the Iberian pig, a slow-growing, obese porcine breed, are not well defined and seem to differ from those of conventional or high-performing pigs. The effects of the dietary protein content and the feeding level on the utilisation of metabolisable energy (ME) and the rates of gain, protein, and fat deposition were studied with 81 Iberian castrates growing from 50 to $100 \mathrm{~kg}$ body weight (BW) by using the comparative slaughter technique. The animals were fed 4 diets providing 145, 120, 95, and $70 \mathrm{~g}$ ideal crude protein (CP) per $\mathrm{kg}$ dry matter (DM), and containing 13.94, 14.29, 14.56, and 14.83 MJ ME per $\mathrm{kg} D \mathrm{DM}$, respectively. Three levels of feeding were evaluated: $0.60,0.80$, and $0.95 \times$ ad libitum intake. Growth rate increased (linear and quadratic, $\mathrm{P}<0.001$ ) as the dietary ideal CP content decreased. It also increased with the feeding level (linear, $\mathrm{P}<0.001$; quadratic, $\mathrm{P}<0.05$ ). Gain:feed and gain:ME intake improved by decreasing the ideal $C P$ content in the diet (linear, $\mathrm{P}<0.001$ and $\mathrm{P}<0.05$, respectively; quadratic $\mathrm{P}<0.001$ for both variables). Increasing the feeding level improved linearly gain:feed and gain:ME intake $(P<0.001)$. Protein deposition (PD):ME intake ranged between 1.23 and $1.44 \mathrm{~g} / \mathrm{MJ}$, and it showed a tendency to reach the maximum value when the diet providing $95 \mathrm{~g}$ ideal CP per $\mathrm{kg}$ DM was fed (quadratic, $\mathrm{P}=0.078$ ). When this diet was offered at $0.95 \times$ ad libitum, $P D$ reached a maximum value of $71 \mathrm{~g} /$ day. This dietary treatment resulted in average values for average daily gain and retained energy (RE) of $854 \mathrm{~g} /$ day and $21.4 \mathrm{MJ} /$ day, respectively. The average rate of gain was $19.93 \mathrm{~g} / \mathrm{MJ}$ increase in ME intake, equivalent to an energy cost of $50.2 \mathrm{~kJ} \mathrm{ME}$ per g gain, irrespective of the dietary ideal $C P$ content. Also, the overall marginal efficiency of protein deposition ( $\triangle P D: \triangle M E ; g / M J)$ was 1.34. Increasing the feeding level led to increases in $P D$ (linear, $\mathrm{P}<0.001$ ) and $R E$ (linear, $\mathrm{P}<0.001$; quadratic, $\mathrm{P}<0.01$ ) irrespective of the dietary ideal CP concentrations. Between 50 and $100 \mathrm{~kg} \mathrm{BW}$, the chemical composition of $1 \mathrm{~kg}$ gain averaged 78, 592, 28.7, and $284 \mathrm{~g}$ for $C P$, fat, ash, and water respectively. The net efficiency of use of $M E$ for growth $\left(\mathrm{k}_{\mathrm{g}}\right)$ and the maintenance energy requirements were 0.606 and $396 \mathrm{~kJ} / \mathrm{kg} \mathrm{BW} W^{0.75}$ per day, respectively. The results support earlier findings that the genotype has marked effects on protein and energy metabolism of growing pigs and underline important compositional differences of the Iberian pig compared with conventional or modern porcine genotypes.

Keywords: energy requirement, energy retention, pigs, protein requirement, protein retention

\section{Introduction}

Extensive systems to produce heavy pigs (slaughtered at 140 to $180 \mathrm{~kg}$ body weight (BW) and 18 to 25 months of age) are typically located in some regions of the Mediterranean area. Their low productivity encourages current tendencies to shorten their productive cycle by intensification of management during the growing and early stages

\footnotetext{
${ }^{\dagger}$ E-mail: jose.aguilera@eez.csic.es
}

of the finishing period. The nutritional requirements of the Iberian pig (Sus mediterraneus), a slow-growing, obese porcine breed, are not well defined and seem to differ from those of conventional (standard performance) or high-performing pigs. Nieto et al. (2002) demonstrated that the optimal dietary protein to energy ratio was considerably lower in Iberian pigs growing from 15 to $50 \mathrm{~kg}$ BW than in pigs with a greater genetic potential for protein deposition (PD) (Campbell et al., 1985; Kyriazakis and Emmans, 1992). Maximal PD (74 g/day) was achieved with 
a diet supplying $6.86 \mathrm{~g}$ digestible ideal crude protein (CP) per MJ metabolisable energy (ME) fed close to ad libitum intake. Although conflicting results have been reported (Siebrits et al., 1986; Whittemore et al., 1988; Möhn and De Lange, 1998), the relationship between PD and energy intake may change as the animal increases BW. To test this hypothesis in the growing-fattening Iberian pig (50 to $100 \mathrm{~kg} \mathrm{BW}$ ) a wide range of dietary protein to energy ratios were assayed. In this way an appropriate balance between ideal CP and energy concentrations can be established and the response of the animals to changes in energy or amino acid (AA) supply can be predicted. To achieve our objective, the optimal supply of dietary ideal $\mathrm{CP}$ leading to maximum daily rates of $\mathrm{PD}\left(\mathrm{PD}_{\max }\right)$ and the marginal efficiency of body PD (Fuller et al., 1995), i.e., the change in daily PD per unit change in daily $M E$ at restricted intakes ( $\triangle \mathrm{PD}: \Delta \mathrm{ME} ; \mathrm{g} / \mathrm{MJ})$, were considered. A second objective was to establish reliable estimates of energy utilisation in the growing-fattening pig. This information, together with corresponding data on carcass quality as the main source of edible products, is relevant for application in the practical feeding of heavier animals prior to their extensive management. At this respect, in a previous paper we have reported that both the protein to energy ratio of the diet and the level of feeding affected carcass quality (Barea et al., 2006). Also, altering the feed intake resulted in significant changes in carcass and viscera as proportions of empty BW.

\section{Material and methods}

\section{Animals and experimental design}

As described in the previous paper (Barea et al., 2006), three groups of purebred castrated male Iberian pigs of Silvela strain were used. They were from the same herd of pigs used in our previous experiment (Nieto et al., 2002). The protein and energy content of the standard diet given to the experimental pigs before the beginning of the experiments were similar to our previous study (Nieto et al., 2002). In total, 81 lberian castrates, $49.9 \pm 0.0 \mathrm{~kg}$ initial BW, were randomly assigned to 4 diets containing 145 to $70 \mathrm{~g}$ ideal $\mathrm{CP}$ per $\mathrm{kg}$ dry matter (DM) and three feeding levels (FL) in a factorial arrangement of treatments with six to seven individually housed pigs per treatment. Due to the availability of only 28 individual pens, the experiment was conducted in three replicates, each with two or three pigs per treatment. When establishing the ideal $\mathrm{CP}$ for dietary treatments, it was assumed that the $\mathrm{PD}_{\max }$ value for the growing-fattening pig would be somewhat lower than the rate previously observed in the younger pig (Nieto et al., 2002). In that study, the $P D_{\max }$ was obtained with a diet providing $6.86 \mathrm{~g}$ digestible ideal $C P$ per $M J M E$, a value which is within the range of the values used in the present experiment. The range of $\mathrm{FL}$ was chosen to allow an accurate estimation of the efficiency of dietary energy utilisation, while the higher allowances are usual in a practical feeding.
Diets and feeding

Four diets of similar ME concentration were formulated to contain $145,120,95$, and $70 \mathrm{~g}$ ideal CP per $\mathrm{kg}$ DM. These diets were prepared by mixing a protein-free diluting mixture and a high-protein (HP) diet (Table 1). The HP diet was formulated to provide an optimal pattern of amino acids (Table 2), according to the ideal protein concept (Agricultural Research Council (ARC), 1981). The diluting mixture was made to match the macronutrient content of the HP diet. In this way, the relative proportions of nutrients in the experimental diets would remain constant, except for the replacement of CP by starch, which causes a slight increase in ME concentration. However, this increase in the energy value was considered irrelevant because the key factor affecting PD in the pig is the amount of digestible ideal $C P$ per unit of $M E$, which resulted to be $8.05,6.50,5.20$ and $3.65 \mathrm{~g} / \mathrm{MJ}$. Each of the four diets was offered at three FL $(0.95,0.80$ and $0.60 \times$ ad libitum intake) daily in two equal meals. Water was available ad libitum.

Table 1 Composition and chemical analysis of the high-protein (HP) diet

\begin{tabular}{lc}
\hline \hline HP diet & Content \\
\hline Ingredients (g/kg as fed) & \\
Barley grain & 947 \\
Soya-bean meal & 15 \\
Dibasic calcium phosphate & 12 \\
Calcium carbonate & 11 \\
Common salt & 5 \\
Vitamin/mineral pre-mix ${ }^{\dagger}$ & 3 \\
L-Lys HCl ${ }^{\ddagger}$ & 5 \\
L-Thr & \\
L-His & \\
Diluting mixture & \\
Analysed nutrient composition (g/kg as fed) & 1.5 \\
Crude protein & 0.15 \\
Lysine & - \\
Methionine and cystine & 127.9 \\
Threonine & 8.72 \\
Tryptophan & 5.31 \\
Isoleucine & 5.60 \\
Leucine & 1.34 \\
Histidine & 4.69 \\
Phenylalanine and tyrosine & 8.49 \\
Valine & 2.80 \\
Lipids & 10.42 \\
Acid-detergent fibre & 6.57 \\
Dry matter & 15.71 \\
\hline \hline
\end{tabular}

${ }^{\dagger}$ Provided the following per $\mathrm{kg}$ diet: retinol, $3.38 \mathrm{mg}$ as retinyl acetate; cholecalciferol, $56.3 \mu \mathrm{g}$; DL- $\alpha$-tocopherol, $2.52 \mathrm{mg}$ as DL- $\alpha$-tocopheryl acetate; menadione, $1.5 \mathrm{mg}$ as menadione sodium bisulfite; thiamine, $0.15 \mathrm{mg}$; riboflavin, $3 \mathrm{mg}$; pyridoxine, $0.15 \mathrm{mg}$; cyanocobalamin, $15 \mu \mathrm{g}$; folic acid, $15 \mu \mathrm{g}$; nicotinic acid, $22.5 \mathrm{mg}$; D-pantothenic acid, $15 \mathrm{mg}$ as calcium pantothenate; $\mathrm{Mn}, 15 \mathrm{mg}$ as $\mathrm{MnSO}_{4} .4 \mathrm{H}_{2} \mathrm{O} ; \mathrm{Fe}, 75 \mathrm{mg}$ as $\mathrm{FeSO}_{4} .7 \mathrm{H}_{2} \mathrm{O} ; \mathrm{Zn}, 120 \mathrm{mg}$ as $\mathrm{ZnO} ; \mathrm{I}, 450 \mu \mathrm{g}$ as Kl; $\mathrm{Cu}, 60 \mathrm{mg}$ as $\mathrm{CuSO}_{4} \cdot 5 \mathrm{H}_{2} \mathrm{O} ; \mathrm{Co}, 300 \mu \mathrm{g}$ as $\mathrm{CoSO}_{4} .7 \mathrm{H}_{2} \mathrm{O}$.

${ }^{\ddagger}{ }_{\mathrm{L}}$-Lys $\mathrm{HCl}$ containing $78.8 \% \mathrm{~L}$-Lys; L-Thr and L-His, added as free base, 98.5 and $100 \% \mathrm{~L}-\mathrm{Thr}$ and L-His, respectively.

${ }_{\S}^{\S}$ Mixed with HP diet to prepare experimental diets. Containing $(\mathrm{g} / \mathrm{kg}$, as fed): maize starch, 883.1; cellulose, 64.2; dibasic calcium phosphate, 29; corn oil (containing butylated hidroxytoluene to provide $0.125 \mathrm{~g}$ per kg diluting mixture), 15.7; common salt, 5; vitamin/mineral pre-mix, 3. Analysed chemical composition ( $\mathrm{g} / \mathrm{kg})$ : total $\mathrm{N},<0.5$; dry matter, 878 . 
Table 2 Nutrient composition of the experimental diets obtained by dilution of a high-protein (HP) diet with a diluting mixture based on maize starch

\begin{tabular}{|c|c|c|c|c|}
\hline & \multicolumn{4}{|c|}{$\begin{array}{c}\text { Experimental } \\
\text { diet ( } \mathrm{g} \text { ideal CP per kg DM) }\end{array}$} \\
\hline & 145 & 120 & 95 & 70 \\
\hline \multicolumn{5}{|c|}{ Proportion of HP diet and dilution mixture $(\mathrm{g} / \mathrm{kg})$} \\
\hline HP diet & 1000 & 828 & 656 & 483 \\
\hline Diluting mixture & 0 & 172 & 344 & 517 \\
\hline \multicolumn{5}{|l|}{ Calculated composition $^{\dagger}$} \\
\hline TDP (g/kg DM) & 123 & 102 & 81 & 60 \\
\hline TDLys (g/kg DM) & 8.86 & 7.34 & 5.82 & 4.28 \\
\hline TDLys/TDP (g/kg) & 72 & 72 & 72 & 71 \\
\hline TDLys/ME (g/MJ) & 0.63 & 0.52 & 0.40 & 0.29 \\
\hline \multicolumn{5}{|l|}{ TDAA/TDLys } \\
\hline Methionine and cystine & 0.59 & 0.59 & 0.59 & 0.59 \\
\hline Threonine & 0.62 & 0.62 & 0.62 & 0.62 \\
\hline Tryptophan & 0.14 & 0.14 & 0.14 & 0.14 \\
\hline Isoleucine & 0.51 & 0.51 & 0.51 & 0.51 \\
\hline Leucine & 0.94 & 0.94 & 0.94 & 0.94 \\
\hline Histidine & 0.31 & 0.31 & 0.31 & 0.31 \\
\hline Phenylalanine and tyrosine & 1.17 & 1.17 & 1.17 & 1.17 \\
\hline Valine & 0.69 & 0.69 & 0.69 & 0.69 \\
\hline ME (MJ/kg DM) & 14.0 & 14.2 & 14.4 & 14.6 \\
\hline DP:ME (g/MJ) & 8.05 & 6.50 & 5.20 & 3.65 \\
\hline
\end{tabular}

${ }^{\dagger}$ TDP: true digestible protein; TDLys: true digestible lysine; TDAA/TDLys: true digestible amino acid relative to TDLys; DP: apparent digestible ideal CP; DM: dry matter.

The ad libitum intake was defined as what the pig would consume when given sole access to its respective diet for two periods of $60 \mathrm{~min} /$ day, and it was estimated previously by offering similar diets to those used in the present experiment to individually housed castrated male lberian pigs (50 to $85 \mathrm{~kg} \mathrm{BW}$ ) in a room maintained at $19.0 \pm 1.5^{\circ} \mathrm{C}$ (Nieto et al., 2001). Based on the BW of the pig, the daily allowance was determined weekly prior to feeding using the formula:

$$
\begin{aligned}
& \text { voluntary intake }(\mathrm{g} / \text { day, as-fed basis }) \\
& =1525(\text { s.e.164) }+31.3(\text { s.e.2.3 }) \times \mathrm{BW}(\mathrm{kg}) \\
& \qquad\left(P<0.001 ; \mathrm{n}=20 ; R^{2}=0.557\right)
\end{aligned}
$$

\section{Pig performance and digestibility measurements}

On arrival, pigs were group-housed and given ad libitum access to a barley-soybean meal-based diet containing $165 \mathrm{~g}$ ideal CP per $\mathrm{kg}$ DM and approximately 14.5 MJ ME per $\mathrm{kg}$ DM until they reached $50 \mathrm{~kg}$. Pigs were then housed in individual pens $\left(2 \mathrm{~m}^{2}\right)$ located in a environmentally controlled room $\left(19.0 \pm 1.5^{\circ} \mathrm{C}\right)$ until they reached $100 \mathrm{~kg}$ when they were slaughtered. During the experiment, the pigs were weighed once per week before feeding and for each animal the daily feed allowance for the following week was adjusted accordingly. Digestibility trials were conducted at approximately $75 \mathrm{~kg} \mathrm{BW}$, as described in Barea et al. (2006). Apparent energy digestibility [d(E)] and metabolisability $[\mathrm{m}(\mathrm{E})]$ were calculated as digestible energy (DE): gross energy (GE) and ME:GE ratios.
Comparative slaughter measurements

At $100 \mathrm{~kg} \mathrm{BW}$ the pigs were electrically stunned and bled, and blood was collected. After emptying the gut, carcass and non-carcass parts were weighed separately. Viscera and blood were kept at $-20^{\circ} \mathrm{C}$ until analysis. The eviscerated carcass with head, feet and tail were chilled overnight and weighed. Four components were obtained for each pig: carcass, head (together with feet and tail), viscera and blood. The carcass without head was split longitudinally. After weighing both halves, they were sealed in plastic bags and kept at $-20^{\circ} \mathrm{C}$ until analysis. The right half of the carcass and the rest of components were cut into small pieces and ground in a mincer (Talleres Cato, Sabadell, Spain) separately, homogenised in a cutter (Talleres Cato, Sabadell, Spain), and sub-samples were taken for freeze-drying and subsequent analysis. Aliquot samples were analysed for DM content, CP (total $N \times 6.25$ ), GE and ash. Body fat was calculated from total body GE assuming an energy content of 23.85 and $39.75 \mathrm{~kJ} / \mathrm{g}$ for protein and fat, respectively.

To predict body composition of the experimental pigs at the start of the trial, the data from 18 additional pigs were obtained from the previous experiment carried out in Iberian pigs growing from 15 to $50 \mathrm{~kg} \mathrm{BW}$ (Nieto et al., 2002). These pigs were offered diets containing 175 and $156 \mathrm{~g}$ ideal CP per kg DM with 14.4 and 14.8 MJ ME per kg DM, respectively, at 0.80 and $0.95 \times$ ad libitum. Small and not significant differences in whole-body composition due to the treatments imposed were observed. Pigs were slaughtered before initiating the present experiment. The relationships between live and empty BW at slaughter and the analysed body composition obtained both in the previous experiment were used to estimate the initial body composition of pigs used in the present experiment. Total body composition was calculated from the chemical composition of the four body components and their respective weights. Increases in protein (determined as total nitrogen ( $\mathrm{N}$ ) retention), energy, fat and minerals were then calculated as the difference between final measured composition of experimental pigs and estimated initial composition assessed from the initial group. The experimental protocol was approved by the Bioethical Committee of the Spanish Council for Scientific Research (CSIC), Spain.

\section{Chemical analysis}

All analyses were performed in duplicate. The DM content of feeds and faeces was determined (Association of Official Analytical Chemists (AOAC), 1990). Whenever an analysis was made on a freeze-dried material, the DM content of an aliquot sample was determined in a ventilated oven to estimate the residual moisture content after freeze-drying, and the corresponding result was expressed on a DM basis. Total lipids in feeds were determined by ether extraction (AOAC, 1990). Acid-detergent fibre content in feed samples was analysed by the method of Goering and Van Soest (1970). Total $\mathrm{N}$ in feed, urine, freeze-dried samples of body components (except blood), and faeces was determined by the Kjeldahl procedure. After hydrolysis with $6 \mathrm{~mol} / \mathrm{l} \mathrm{HCl}$ plus $1 \%$ phenol in sealed, evacuated tubes at $110^{\circ} \mathrm{C}$ for $24 \mathrm{~h}$, amino 
acids in feed samples was determined by HPLC according to the Waters Pico Tag method (Cohen et al., 1989). Cysteine and methionine were determined as cysteic acid and methionine sulphone, respectively, after oxidation with performic acid before hydrolysis with $6 \mathrm{~mol} / \mathrm{l} \mathrm{HCl}$ (Moore, 1963). The total ash content of feed and freeze-dried body components samples was determined (AOAC, 1990). The GE content of feed, freeze-dried body components, and faecal samples was measured in an adiabatic bomb calorimeter (Gallenkamp Autobomb CBA 305, Loughborough, UK). Urine was freezedried in a polyethylene sheet of known energy value and their $\mathrm{GE}$ values were obtained by difference.

\section{Statistical analysis}

The data were subjected to an analysis of variance using the GLM procedure of Statistical Analysis Systems Institute (1990). The individual pig was used as the experimental unit. The effects of dietary ideal CP, FL, block (or replication) and all possible interactions were included in the initial statistical model. With no significant block effect or no treatment by block interactions, these terms were deleted from the statistical model for subsequent analyses. Orthogonal polynomials were used to determine linear and quadratic effects of the dietary ideal $\mathrm{CP}$ and the $\mathrm{FL}$ on response criteria.

\section{Regression analyses}

Linear regressions were calculated for each experimental diet to relate rate of gain (g/day) and ME intake. For this purpose the average value of the whole feeding period for each pig was used. All experimental diets resulted in homogeneous regression coefficients and a composite regression was developed for the pooled data. The marginal efficiency of body PD ( $\Delta \mathrm{PD}: \Delta \mathrm{ME}, \mathrm{g} / \mathrm{MJ}$ ) was estimated by linear regressions with individual data from the different dietary treatments. All diets resulted in homogeneous regressions. The intercept of the composite regression calculated on pooled data did not differ significantly from zero, and a new regression forced to the origin was constructed.

To predict energy maintenance requirements $\left(\mathrm{ME}_{\mathrm{m}}\right)$ and calculate net efficiencies of energy utilisation in the growing animal $\left(k_{g}\right)$, ME intake $\left(\mathrm{kJ} / \mathrm{kg} \mathrm{BW} \mathrm{W}^{0.75}\right.$ per day) was related to the total retained energy ( $\mathrm{RE}, \mathrm{kJ} / \mathrm{kg} \mathrm{BW} \mathrm{BW}^{0.75}$ per day) by linear regression equations using ME intake as either an independent or dependent variable. Separate regressions were calculated within the dietary ideal CP content. All diets showed homogeneous regression coefficients, and pooled equations were established accordingly. Estimates of the partial efficiency of the ME utilisation for PD $\left(k_{p}\right)$ and fat deposition $\left(\mathrm{k}_{\mathrm{f}}\right)$ were calculated by a multiple regression equation (Kielanowski, 1965), using ME intake ( $\mathrm{kJ} / \mathrm{kg} \mathrm{BW}^{0.75}$ per day) as a dependent variable and energy retained as protein and fat $\left(\mathrm{RE}_{\mathrm{p}}\right.$ and $\mathrm{RE}_{\mathrm{f}}$, respectively, $\mathrm{kJ} / \mathrm{kg} \mathrm{BW} \mathrm{B}^{0.75}$ per day) as independent variables. An equation was derived with the pooled data for the four dietary treatments.

\section{Results}

All pigs were in good health during the whole trial. No feed refusals were observed except for some pigs on the feeding level closer to ad libitum. Any refusals were collected each morning, dried to a constant weight and weighed to calculate the actual consumption.

\section{Feed intake and digestibility measurements}

Feed intake was not affected by the dietary ideal CP content and averaged $2.58 \mathrm{~kg}$ DM per day (Table 3). There were linear $(P<0.01)$ and quadratic $(P<0.01)$ effects of the $\mathrm{FL}$ on feed intake. Average daily DE and ME intakes were 29.2 and 28.7, 38.6 and 37.9 , and 45.4 and $44.6 \mathrm{MJ}$ for the three $\mathrm{FL}$, respectively. The digestibility and metabolisability of energy increased linearly $(P<0.001)$ by decreasing the ideal $C P$ content of the diet (Table 3). The decreases in $d(E)$ and $m(E)$ were partially due to the dilution of the HP diet with a slightly higher digestible protein-free mixture. The change in the value was slightly higher for $m(E)$, which increased from 0.772 to 0.852 by decreasing the dietary ideal CP content from 145 to $70 \mathrm{~g} / \mathrm{kg} \mathrm{DM}$. On average, the energy density of the diets increased from 13.94, 14.29, 14.56 and 14.83 MJ ME per $\mathrm{kg} \mathrm{DM}$ by the reduction in the ideal CP content. Linear $(P=0.01$ and $P<0.001)$ and quadratic $(P<0.05$ and $P<0.01$ respectively) effects of the $F L$ on $d(E)$ and $m(E)$

Table 3 Effects of dietary protein content (DPC) and level of feeding ( $F L)$ on the digestibility of energy $(d(E))$ and nitrogen $(d(N))$ and metabolisability of energy $(m(E))$ in Iberian pigs growing from 50 to $100 \mathrm{~kg}$ body weight (mean values for 20 or 21 pigs per DPC group)

\begin{tabular}{|c|c|c|c|c|c|c|c|c|c|c|c|c|}
\hline & & & & & & & & & \multicolumn{4}{|c|}{$\begin{array}{c}\text { Statistical } \\
\text { significance }^{\dagger}\end{array}$} \\
\hline & \multicolumn{4}{|c|}{ DPC (g/kg DM) } & \multicolumn{4}{|c|}{$\mathrm{FL}(\times$ ad libitum $)$} & \multicolumn{2}{|c|}{ DPC } & \multicolumn{2}{|c|}{$\mathrm{FL}$} \\
\hline & 145 & 120 & 95 & 70 & 0.95 & 0.80 & 0.60 & Pooled s.d. & $\mathrm{L}$ & Q & $\mathrm{L}$ & Q \\
\hline Feed intake (kg DM per day) & 2.58 & 2.59 & 2.57 & 2.56 & 3.10 & 2.64 & 1.98 & 0.06 & & & $* * *$ & $* * *$ \\
\hline Digestible energy (DE) intake (MJ/day) & 36.9 & 37.7 & 38.0 & 38.4 & 45.4 & 38.6 & 29.2 & 1.1 & $* * *$ & & $* * *$ & *** \\
\hline Metabolisable energy (ME) intake (MJ/day) & 36.0 & 37.0 & 37.4 & 37.9 & 44.6 & 37.9 & 28.7 & 1.0 & $* * *$ & & $* * *$ & $* * *$ \\
\hline$d(E)$ & 0.792 & 0.819 & 0.839 & 0.862 & 0.826 & 0.824 & 0.835 & 0.013 & $* * *$ & & $* *$ & * \\
\hline$m(E)$ & 0.772 & 0.802 & 0.825 & 0.852 & 0.810 & 0.808 & 0.820 & 0.012 & $* * *$ & & $* *$ & * \\
\hline ME:DE & 0.974 & 0.980 & 0.983 & 0.988 & 0.982 & 0.981 & 0.981 & 0.007 & $* * *$ & & & \\
\hline$d(N)$ & 0.775 & 0.775 & 0.779 & 0.757 & 0.756 & 0.768 & 0.791 & 0.028 & & & $* * *$ & \\
\hline
\end{tabular}

${ }^{\dagger} L=$ linear contrast; $Q=$ quadratic contrast. DPC $\times F L$ interactions were not significant $(P>0.05)$. 
were observed, with the $0.60 \times$ ad libitum intake resulting in the highest $d(E)$ and $m(E)$ ratios. The ME:DE ratio increased linearly with decreasing the ideal CP content of the diet $(P<0.001)$, but it remained close to 0.98 regardless of the feeding allowance.

Apparent digestible N:N intake (or apparent digestibility of $(P)$ was unaffected by the dietary ideal CP. But, it increased linearly from 0.756 to 0.791 by decreasing the $\mathrm{FL}$ $(P<0.001)$.

\section{Growth performance}

Average daily gain (ADG), gain:feed and gain:ME intake are shown in Table 4. ADG increased (linear and quadratic, $P<0.001)$ by decreasing the dietary $C P$ content. As expected, $A D G$ increased with the $F L$ (linear, $P<0.001$; quadratic, $P<0.05)$. Gain:feed and gain:ME intake improved by decreasing the ideal $\mathrm{CP}$ content in the diet (linear, $P<0.001$ and $P<0.05$, respectively; quadratic $P<0.001$ for both variables). The diet supplying $95 \mathrm{~g}$ ideal $\mathrm{CP}$ per $\mathrm{kg} \mathrm{DM}$ resulted in a relative greater gain:ME intake than those containing 145 or $70 \mathrm{~g}$ ideal CP per $\mathrm{kg}$ DM. Increasing the $\mathrm{FL}$ improved linearly gain:feed intake and gain:ME intake $(P<0.001)$. No interactions were observed.

Equation [1] is a composite regression developed for the rate of gain and ME intake based on the pooled data irrespective of the dietary ideal CP because all diets resulted in homogeneous slopes. The regression coefficient shows an average increase of $19.93 \mathrm{~g}$ gain per $\mathrm{MJ}$ increase in $\mathrm{ME}$ intake, equivalent to an energy cost of $50.2 \mathrm{~kJ} \mathrm{ME} / \mathrm{g}$ gain (1/19.93):

$$
\begin{aligned}
\operatorname{gain}(\mathrm{g} / \text { day })= & -90.0(\text { s.e. } 21.7)+19.93(\text { s.e.0.57 }) \\
& \times \text { ME intake }(\mathrm{MJ} / \text { day }) \\
& \left(\mathrm{n}=81 ; R^{2}=0.940 ; P<0.001\right)
\end{aligned}
$$

\section{Protein deposition}

Mean estimated initial body composition at $50 \mathrm{~kg}$ BW was $137.1 \pm 1.3,324.9 \pm 6.3,32.9 \pm 0.8$ and $502.2 \pm 5.4 \mathrm{~g} / \mathrm{kg}$ empty BW for protein, fat, ash and water, respectively. There were no interactions between the dietary ideal CP content and the FL for PD variables (Table 4). There was a quadratic response $(P<0.05)$ in the rate of $P D$ as dietary ideal $C P$ content decreased. However, the decrease in the FL reduced linearly the rate of PD $(P<0.001)$. Nitrogen retained (obtained by comparative slaughter measurements): $\mathrm{N}$ intake and $\mathrm{N}$ retained:apparent digestible $\mathrm{N}$ improved linearly with the decrease in the dietary ideal CP content $(P<0.001)$. Increasing the FL from 0.60 to 0.80 or $0.95 \times$ ad libitum reduced $N$ retained: $\mathrm{N}$ intake and $\mathrm{N}$ retained:apparent digestible $\mathrm{N}$ in a quadratic pattern $(P<0.05$ for both variables). Protein deposition:ME intake ranged between 1.23 and 1.44. There were tendencies for quadratic responses in PD:ME intake of dietary ideal $\mathrm{CP}$ content and $\mathrm{FL}(P=0.078$ and 0.058 , respectively).

The pooled equation [2], obtained with data from all diets, shows a marginal efficiency of body PD ( $\triangle \mathrm{PD}: \triangle \mathrm{ME}$; $\mathrm{g} / \mathrm{MJ})$ of $1.34 \mathrm{~g}$. This indicates that within the range of the dietary ideal CP content investigated, each additional MJ in $\mathrm{ME}$ at restricted intakes was associated with $1.34 \mathrm{~g}$ of PD in the lberian pig growing from 50 to $100 \mathrm{~kg} \mathrm{BW:}$

$$
\begin{array}{r}
\mathrm{PD}(\mathrm{g} / \text { day })=1.34(\text { s.e. } 0.03) \times \mathrm{ME} \text { intake }(\mathrm{MJ} / \text { day }) \\
(\mathrm{n}=81 ; P<0.001)
\end{array}
$$

\section{Energy utilisation}

Data from energy retention and their partition into protein and fat deposition expressed in $\mathrm{kJ} / \mathrm{kg} \mathrm{BW}^{0.75}$ per day are presented in Table 5. No interactions between the dietary ideal $\mathrm{CP}$ content or the FL were noted. Retained energy increased linearly $(P<0.001)$ by decreasing the ideal $C P$ content in the diet and showed linear $(P<0.001)$ and quadratic responses on increasing the $\mathrm{FL}(P<0.01)$. Retained energy as protein increased in a quadratic pattern by decreasing the dietary

\begin{tabular}{|c|c|c|c|c|c|c|c|c|c|c|c|c|}
\hline & & & & & & & & & \multicolumn{4}{|c|}{$\begin{array}{c}\text { Statistical } \\
\text { significance }^{\dagger}\end{array}$} \\
\hline & \multicolumn{4}{|c|}{ DPC (g/kg DM) } & \multicolumn{4}{|c|}{$\mathrm{FL}(\times$ ad libitum $)$} & \multicolumn{2}{|c|}{ DPC } & \multicolumn{2}{|c|}{$\mathrm{FL}$} \\
\hline & 145 & 120 & 95 & 70 & 0.95 & 0.80 & 0.60 & Pooled s.d. & L & Q & L & Q \\
\hline Average daily gain $(\mathrm{g})$ & 606 & 655 & 681 & 659 & 800 & 667 & 484 & 44 & $* * *$ & *** & *** & * \\
\hline Gain:feed intake (g/kg) & 234.3 & 252.1 & 263.5 & 256.9 & 257.5 & 252.5 & 245.1 & 0.2 & $* * *$ & $* * *$ & $* * *$ & \\
\hline Gain:ME intake (g/MJ) & 16.80 & 17.64 & 18.11 & 17.33 & 17.93 & 17.61 & 16.87 & 0.85 & * & $* * *$ & $* * *$ & \\
\hline $\mathrm{PD}^{\S}(\mathrm{g} \mathrm{N}$ retained $\times 6.25$ per day $)$ & 49 & 51 & 54 & 46 & 60 & 48 & 42 & 10 & & * & $* * *$ & \\
\hline $\mathrm{N}$ retained: $\mathrm{N}$ intake $(\mathrm{g} / \mathrm{g})$ & 0.133 & 0.163 & 0.217 & 0.252 & 0.191 & 0.179 & 0.205 & 0.036 & $* * *$ & & & * \\
\hline$N$ retained:ApDN|| $(\mathrm{g} / \mathrm{g})$ & 0.172 & 0.210 & 0.273 & 0.333 & 0.248 & 0.233 & 0.260 & 0.045 & $* * *$ & & & * \\
\hline PD:ME intake (g/MJ) & 1.38 & 1.38 & 1.44 & 1.23 & 1.34 & 1.28 & 1.45 & 0.26 & & $\neq$ & & $\neq$ \\
\hline
\end{tabular}
ideal CP content $(P<0.05)$, and linearly $(P<0.001)$ with increasing the FL. Energy deposition as fat increased linearly

Table 4 Effects of dietary protein content (DPC) and level of feeding (FL) on the performance and protein deposition of Iberian pigs growing from 50 to $100 \mathrm{~kg}$ body weight (mean values for 20 or 21 pigs per DPC group)

\footnotetext{
${ }^{\dagger} \mathrm{L}=$ linear contrast; $\mathrm{Q}=$ quadratic contrast. DPC $\times \mathrm{FL}$ interactions were not significant $(P>0.05)$.

${ }^{\ddagger}$ Approaching significance $(P<0.1)$.

${ }^{\S} \mathrm{PD}$, protein deposition.

"ApDN, apparent digestible nitrogen.
} 
Barea, Nieto and Aguilera

Table 5 Effects of dietary protein content (DPC) and level of feeding (FL) on the energy balance of Iberian pigs growing from 50 to $100 \mathrm{~kg}$ body weight (BW) (mean values for 20 or 21 pigs per DPC group)

\begin{tabular}{|c|c|c|c|c|c|c|c|c|c|c|c|c|}
\hline & & & & & & & & & \multicolumn{4}{|c|}{$\begin{array}{c}\text { Statistical } \\
\text { significance }^{\dagger}\end{array}$} \\
\hline & \multicolumn{4}{|c|}{ DPC (g/kg DM) } & \multicolumn{4}{|c|}{$\mathrm{FL}(\times$ ad libitum $)$} & \multicolumn{2}{|c|}{ DPC } & \multicolumn{2}{|c|}{$\mathrm{FL}$} \\
\hline & 145 & 120 & 95 & 70 & 0.95 & 0.80 & 0.60 & Pooled s.d. & $\mathrm{L}$ & Q & $\mathrm{L}$ & Q \\
\hline DE intake $\left(\mathrm{kJ} / \mathrm{kg} \mathrm{BW}^{0.75}\right.$ per day) & 1491 & 1517 & 1532 & 1539 & 1835 & 1552 & 1172 & 45 & $* * *$ & & $* * *$ & $* * *$ \\
\hline ME intake (kJ/kg BW ${ }^{0.75}$ per day) & 1454 & 1486 & 1506 & 1520 & 1801 & 1522 & 1151 & 40 & $* * *$ & & *** & *** \\
\hline $\mathrm{RE}^{\ddagger}\left(\mathrm{kJ} / \mathrm{kg} \mathrm{BW}^{0.75}\right.$ per day $)$ & 617 & 650 & 695 & 702 & 829 & 689 & 481 & 53 & $* * *$ & & *** & ** \\
\hline $\mathrm{RE}_{\mathrm{p}}{ }^{\S}\left(\mathrm{kJ} / \mathrm{kg} \mathrm{BW}{ }^{0.75}\right.$ per day $)$ & 47 & 49 & 52 & 44 & 58 & 46 & 40 & 10 & & * & *** & \\
\hline $\mathrm{RE}^{\|\|}\left(\mathrm{kJ} / \mathrm{kg} \mathrm{BW}^{0.75}\right.$ per day) & 569 & 602 & 643 & 658 & 771 & 642 & 441 & 54 & $* * *$ & & *** & ** \\
\hline RE:ME & 0.420 & 0.433 & 0.459 & 0.459 & 0.460 & 0.452 & 0.417 & 0.029 & $* * *$ & & *** & * \\
\hline $\mathrm{RE}_{\mathrm{p}}: \mathrm{RE}$ & 0.079 & 0.077 & 0.075 & 0.064 & 0.070 & 0.068 & 0.084 & 0.016 & $* *$ & & ** & * \\
\hline $\mathrm{RE}_{\mathrm{f}}^{\mathrm{R}} \mathrm{RE}$ & 0.921 & 0.923 & 0.925 & 0.936 & 0.930 & 0.932 & 0.916 & 0.016 & $* * *$ & & ** & * \\
\hline
\end{tabular}

${ }^{\dagger} \mathrm{L}=$ linear contrast; $\mathrm{Q}=$ quadratic contrast. $\mathrm{DPC} \times \mathrm{FL}$ interactions were not significant.

${ }^{\ddagger} \mathrm{RE}$, total retained energy.

${ }^{\S} \mathrm{RE}_{\mathrm{p}}$, energy retained as protein.

$" R E_{f}$, energy retained as fat.

$(P<0.001)$ by decreasing the dietary ideal $C P$ content and increased linearly $(P<0.001)$ and quadratically $(P<0.01)$ as the FL increased. The overall efficiency of utilisation of the ME for energy gain (RE:ME) improved linearly $(P<0.001)$ as the dietary ideal CP content decreased, whereas it increased linearly as the $\mathrm{FL}$ increased $(P<0.001)$. The proportion of the energy retained as protein or fat to the total energy retained $\left(R E_{p}: R E\right.$ or $R E_{f}: R E$, respectively) was linearly influenced by both factors $(P<0.01$ for dietary protein content and FL). The effect was to increase the proportion of fat deposition in replacement of PD with decreasing the supply of dietary ideal CP and with increasing the FL. Mean values for $\mathrm{RE}_{\mathrm{p}}: \mathrm{RE}$ and $\mathrm{RE}_{\mathrm{f}} \mathrm{RE}$ were $7.4 \%$ (s.e. 0.61 ) and $92.6 \%$ (s.e. 0.61 ) respectively.

Equations [3] and [4] were constructed with data from all diets to predict the energy requirement for maintenance and the net efficiency of energy utilisation in the finishing animal:

$$
\begin{aligned}
& \mathrm{RE}\left[\mathrm{kJ} /\left(\mathrm{kgBW}^{0.75} \text { perday }\right)\right]=-147.7(\text { s.e. } 31.5) \\
& +0.545(\text { s.e. } 0.021) \times \operatorname{ME} \text { intake }\left(\mathrm{kJ} / \mathrm{kgBW}^{0.75} \text { perday }\right) \\
& \qquad\left(\mathrm{n}=81 ; R^{2}=0.899 ; P<0.001\right) \\
& \text { MEintake }\left[\mathrm{kj} /\left(\mathrm{kgBW}^{0.75} \text { perday }\right)\right]=396.0(\text { s.e. } 43.1) \\
& +1.65(\text { s.e. } 0.06) \times \mathrm{RE}\left(\mathrm{kj} / \mathrm{kgBW} \mathrm{B}^{0.75} \text { perday }\right) \\
& \qquad\left(\mathrm{n}=81 ; R^{2}=0.899 ; P<0.001\right)
\end{aligned}
$$

Equation [3] indicates a value of 0.545 for the net efficiency of utilisation of dietary energy for growth $\left(\mathrm{k}_{\mathrm{g}}\right)$, and estimates the $M E$ requirement for maintenance $\left(M E_{m}\right)$ as $272 \mathrm{~kJ} / \mathrm{kg} \mathrm{BW} \mathbf{B W}^{0.75}$ per day. Equation [4] estimates $\mathrm{ME}_{\mathrm{m}}$ as $396 \mathrm{~kJ} / \mathrm{kg} \mathrm{BW}^{0.75}$ per day. The regression coefficient of this equation shows an energetic cost for growth of $1.65 \mathrm{~kJ} \mathrm{ME}$ per $\mathrm{kJ} R E$ and a $\mathrm{k}_{\mathrm{g}}$ value of 0.606 (1/1.65). Estimates of the partial efficiency of the ME utilisation for PD and fat deposition were calculated by the following multiple regression equation:

$$
\begin{aligned}
\text { ME intake }= & 338.4(\text { s.e. } 43.0)+4.58(\text { s.e. } 0.80) \\
& \times \operatorname{RE}_{\mathrm{p}}+1.52(\text { s.e. } 0.07) \\
& \times \mathrm{RE}_{\mathrm{f}}\left(\mathrm{n}=81 ; R^{2}=0.912 ; P<0.001\right)
\end{aligned}
$$

Equation [5] estimates $\mathrm{ME}_{\mathrm{m}}$ as $338 \mathrm{~kJ} /\left(\mathrm{kg} \mathrm{BW} \mathrm{BW}^{0.75}\right.$ per day) and $k_{p}$ and $k_{f}$ as $0.218(1 / 4.58)$ and 0.658 (1/1.52), respectively. From the coefficients of the energy retained as protein and fat, energy costs were estimated to be 109 $(4.58 \times 23.85)$ and $60(1.52 \times 39.75) \mathrm{kJ}$ ME per $g$ for protein and fat, respectively.

\section{Composition of gain}

The empty BW to BW ratio was not affected by experimental treatments and the mean was 0.973 (Table 6). The average rates of deposition of fat, ash, water and energy in the empty BW of Iberian pigs growing from 50 to $100 \mathrm{~kg}$ BW are also presented in Table 6 . Body fat deposition and energy retention increased linearly $(P<0.001)$ with each decrease in the dietary ideal $C P$ content. Similarly to $P D$, water retention showed a quadratic increase $(P<0.01)$ by decreasing the dietary ideal $C P$. The rates of deposition of fat, ash, water and energy were linearly increased $(P<0.001)$ as the FL increased. The mean whole-body chemical composition $(\mathrm{g} / \mathrm{kg})$ at approximately $100 \mathrm{~kg}$ empty BW was $108.8 \pm 2.7,465.6 \pm 9.9,31.2 \pm 2.1$ and $392.0 \pm 8.1$ for protein, fat, ash and water, respectively. Between 50 and $100 \mathrm{~kg}$, the chemical composition of $1 \mathrm{~kg}$ gain averaged $77.6 \pm 4.9,592.2 \pm 19.0,28.7 \pm 2.9$ and $284.0 \pm 15.0 \mathrm{~g}$ for protein, fat, ash and water, respectively.

\section{Discussion}

In the current experiment, the response of Iberian pigs (50 to $100 \mathrm{~kg} \mathrm{BW}$ ) to changes in energy intake at different 
Table 6 Effects of dietary protein content (DPC) and level of feeding (FL) on the rates of deposition of fat, ash, water and energy in the empty BW of Iberian pigs growing from 50 to $100 \mathrm{~kg}$ body weight (BW) (mean values for 20 or 21 pigs per DPC group)

\begin{tabular}{|c|c|c|c|c|c|c|c|c|c|c|c|c|}
\hline & & & & & & & & & \multicolumn{4}{|c|}{$\begin{array}{c}\text { Statistical } \\
\text { significance }^{\dagger}\end{array}$} \\
\hline & \multicolumn{4}{|c|}{$\mathrm{DPC}(\mathrm{g} / \mathrm{kg} \mathrm{DM})$} & \multicolumn{4}{|c|}{$\mathrm{FL}(\times$ ad libitum $)$} & \multicolumn{2}{|c|}{ DPC } & \multicolumn{2}{|c|}{$\mathrm{FL}$} \\
\hline & 145 & 120 & 95 & 70 & 0.95 & 0.80 & 0.60 & Pooled s.d. & $\mathrm{L}$ & $Q$ & $\mathrm{~L}$ & $Q$ \\
\hline Empty BW (kg) & 96.4 & 97.0 & 96.9 & 97.5 & 96.4 & 96.7 & 97.7 & 2.2 & & & * & \\
\hline Empty BW/BW & 0.975 & 0.974 & 0.974 & 0.970 & 0.976 & 0.970 & 0.975 & 0.017 & & & & \\
\hline Fat (g/day) & 354 & 376 & 401 & 413 & 480 & 402 & 277 & 33 & $* * *$ & & $* * *$ & ** \\
\hline Ash (g/day) & 20.1 & 18.2 & 19.4 & 16.2 & 22.8 & 17.2 & 15.4 & 5.7 & $\neq$ & & $* * *$ & \\
\hline Water (g/day) & 175 & 197 & 195 & 171 & 225 & 188 & 140 & 33 & & ** & $* * *$ & \\
\hline Energy (MJ/day) & 15.2 & 16.2 & 17.2 & 17.5 & 20.5 & 17.1 & 12.0 & 1.3 & $* * *$ & & $\star * *$ & ** \\
\hline
\end{tabular}

${ }^{\dagger} \mathrm{L}=$ linear contrast; $\mathrm{Q}=$ quadratic contrast. DPC $\times \mathrm{FL}$ interactions were not significant.

${ }^{\ddagger}$ Approaching significance $(P<0.1)$.

ideal CP concentrations was studied. Expressed on a metabolic BW basis, average ME intakes were 1.15, 1.52 and $1.80 \mathrm{MJ} /\left(\mathrm{kg} \mathrm{BW} \mathrm{BW}^{0.75}\right.$ per day), respectively, for $0.60,0.80$ and $0.95 \times$ ad libitum FL. Taking into account our estimate for $\mathrm{ME}_{\mathrm{m}}\left(396 \mathrm{~kJ} / \mathrm{kg} \mathrm{BW}{ }^{0.75}\right.$ per day) calculated from equation 4, these energy intakes provided 2.9, 3.8 and 4.5 times the maintenance energy requirements for this period of growth.

The rate of growth and PD depended on the $\mathrm{FL}$, and also on the ideal CP content (Table 4). As a result of the low potential for lean tissue deposition in the Iberian pig, the efficiency of utilisation of the dietary ideal CP protein was rather poor, indicating that substantial amounts of the ideal CP provided were used for lipid gain. At fixed energy intakes, the efficiency with which dietary protein was deposited in tissues, expressed either as NR:NI or NR:ApDN, varied inversely with the supply of dietary ideal CP. The result is in agreement with Nieto et al. (2002). The maximum PD in lberian pigs growing from 50 to $100 \mathrm{~kg}$ BW was obtained with the diet supplying $95 \mathrm{~g}$ ideal CP per $\mathrm{kg}$ DM. Taking into account our average apparent digestibility for $\mathrm{CP}$, this diet provided $5.17 \mathrm{~g}$ digestible protein per MJ ME. This CP level also showed the highest PD (71 g/day) when offered at $0.95 \times$ ad libitum. This feeding regimen resulted in ADG of $854 \mathrm{~g} /$ day and RE of $21.4 \mathrm{MJ} /$ day. It should be pointed out that the $\mathrm{PD}_{\max }$ was obtained with $95 \%$ ad libitum, and therefore, might slightly underestimate the $\mathrm{PD}_{\max }$ for these pigs. Nieto et al. (2002) used Iberian pigs growing from 15 and $50 \mathrm{~kg} \mathrm{BW}$ and obtained $\mathrm{PD}_{\max }$ of $74 \mathrm{~g} /$ day when the diet containing $129 \mathrm{~g}$ ideal $\mathrm{CP}$ per $\mathrm{kg}$ DM (providing $6.86 \mathrm{~g}$ digestible ideal CP per MJ $\mathrm{ME})$ was offered close to ad libitum intake. Both values of $\mathrm{PD}_{\max }$ are basically the same for the two periods of growth. This observation is in agreement with results of, among others, Whittemore et al. (1988), Quiniou et al. (1996), and Möhn and De Lange (1998) who found no significant effect of the stage of growth on $\mathrm{PD}_{\max }$, but in contrast with the increasing pattern of the response of PD to live weight up to a peak rate found by others (Thorbek et al., 1984; Tauson et al., 1998; Siebrits et al., 1986).
The maximum capacity for PD obtained in the present work is far lower than values found in lean and conventional genotypes at a similar BW range $(>150 \mathrm{~g} / \mathrm{day}$; Quiniou et al., 1996) and similar to the average value of $75.6 \mathrm{~g} / \mathrm{day}$ in Meishan castrated fed close to ad libitum and growing from 20 to $107 \mathrm{~kg}$ BW (Noblet et al., 1999).

Our results show clearly that the rate of PD was increased as the FL increased even when most of the diets were not limiting in ideal $C P$ supply. The relationship between PD and ME intake was linear and similar for all the ideal CP levels tested (equation [2]). The low marginal efficiency of PD at restricted intakes (1.34 g PD per MJ increase in $\mathrm{ME}$ intake) is associated with the low $\mathrm{PD}_{\max }$ found in the Iberian pig at this stage of growth. This observation confirms the suggestion that the decrease in PD due to restriction in energy allowance would be greater in pigs of higher genetic potential for lean tissue deposition (Campbell and Taverner, 1988; Rao and McCracken, 1991; Quiniou et al., 1996). In Iberian pigs growing from 15 to $50 \mathrm{~kg} \mathrm{BW}$, Nieto et al. (2002) reported a marginal efficiency for PD of $2.81 \mathrm{~g}$ PD per MJ ME with the diet that provided the optimal protein concentration for growth. These results are in the line with previous observations by Black et al. (1986) and Bikker (1994) who reported a decrease in marginal efficiency of PD with BW.

In the present experiment, the increase in the rate of lipid deposition with energy intake averaged $13.05 \mathrm{~g} / \mathrm{MJ}$ ME (12.79 g/MJ DE). This estimate is somewhat below the range of values reported in the literature for pigs of different genotypes growing from 45 to $100 \mathrm{~kg}$ BW (13.3 to 15.0 g/MJ DE; Campbell and Taverner, 1988; Bikker, 1994; Quiniou et al., 1996), indicating a comparatively higher energetic cost of lipid deposition in the body of the Iberian pig. On average, 0.926 of the energy retained was deposited as fat, of which a considerable portion may have been synthesised from dietary amino acids, and, therefore, with a low energetic efficiency. This may explain the low estimates for the net efficiency of energy gain $\left(k_{g}=0.545\right.$ (equation [3]) and 0.606 (equation [4])) and the high energetic cost of fat deposition $\left(k_{f}=0.658\right.$ (equation [5])). 
Nieto et al. (2002) obtained an estimate of 0.582 for $k_{g}$ in Iberian pigs growing from 15 to $50 \mathrm{~kg} \mathrm{BW}$.

We failed to obtain a reliable estimate of the maintenance energy requirements. It is well known that $\mathrm{ME}_{\mathrm{m}}$ estimates are highly dependent on the statistical model used and show a strong correlation with the variables included in the model (Noblet et al., 1999). From equation [3], a very low and unacceptable value is derived. Our estimate of $396 \mathrm{~kJ} / \mathrm{kg} \mathrm{BW}{ }^{0.75}$ per day for $\mathrm{ME}_{\mathrm{m}}$ calculated by equation 4 is slightly lower than the value obtained in our previous study conducted with Iberian pigs growing from 15 to $50 \mathrm{~kg}$ BW $\left(422 \mathrm{~kJ} / \mathrm{kg} \mathrm{BW}^{0.75}\right.$ per day; Nieto et al., 2002) and far lower than the preferred estimate of 458 by the ARC (1981) and the mean estimate of $443 \mathrm{~kJ} / \mathrm{kg}$ $\mathrm{BW}^{0.75}$ per day by National Research Council (NRC, 1998). $A$ decrease in the energy requirement for maintenance is expected because a considerable increase of lipid deposition takes places in pigs growing between 50 and $100 \mathrm{~kg}$ $(327 \mathrm{~g} / \mathrm{kg}$ at $50 \mathrm{~kg}$ empty BW (Nieto et al., 2002) and $466 \mathrm{~g} / \mathrm{kg}$ at $100 \mathrm{~kg}$ empty BW). Meanwhile, the contribution of metabolically active body compartments such as gastro-intestinal tract and liver to whole body size may become less (total viscera ( $\mathrm{g} / \mathrm{kg}$ empty BW), $118 \mathrm{~g}$ at $50 \mathrm{~kg}$ BW (Nieto et al., 2003) v. $98 \mathrm{~g}$ at $100 \mathrm{~kg}$ BW (Barea et al., 2006)). Noblet et al. (1999) and Van Milgen and Noblet (1999) concluded that body muscle and, even more importantly, visceral mass explain a large part in the variation of $M E_{m}$. Higher maintenance energy requirements in lean genotypes are supported by the findings of Thorbek et al. (1984), Campbell and Taverner (1988) and Rao and McCracken (1991).

Our estimates of the partial efficiency of use of ME for protein and fat deposition ( 0.218 and 0.658 , respectively) were associated with a low $\mathrm{ME}_{\mathrm{m}}$. In the experiment conducted with growing Iberian pigs at an earlier stage of growth, Nieto et al. (2002) obtained values of 0.303 and 0.812 for $k_{p}$ and $k_{f}$ respectively, along with a comparatively higher estimate of $\mathrm{ME}_{\mathrm{m}}$. Our present estimations indicate higher energy costs of protein and fat deposition in the Iberian pig in comparison with literature values (ARC, 1981; NRC, 1998). The increased energy cost of synthesising urea to metabolise dietary amino acids in excess of the requirements, and the high protein turnover rate observed in muscle tissue of the Iberian pig (Rivera-Ferre et al., 2005) may explain the low energy efficiency of PD.

In the present experiment, at $100 \mathrm{~kg} \mathrm{BW}$ the empty body of the Iberian pig contained $(\mathrm{g} / \mathrm{kg}) 109$ and $466 \mathrm{~g}$ protein and fat, respectively. Gains of 78 and $592 \mathrm{~g}$ protein and fat per $\mathrm{kg}$, respectively, were deposited on average in the body of the animal between 50 and $100 \mathrm{~kg} \mathrm{BW}$, underlining important compositional differences compared with conventional or modern genotypes of pigs.

In conclusion, in the present experiment the protein and energy requirements of Iberian pigs growing from 50 to $100 \mathrm{~kg} \mathrm{BW}$ are defined. The results support earlier findings that the genotype has marked effects on protein and energy metabolism of growing pigs. The results of the present and previous studies indicate that Iberian pigs growing from 15 to $50 \mathrm{~kg}$ and 50 to $100 \mathrm{~kg} \mathrm{BW}$ have a similar rate of $\mathrm{PD}$. The information is extremely valuable to define feeding strategies, which are economically favourable and environmentally acceptable to achieve optimal growth and maximum efficiency of nutrient utilisation for this Mediterranean pig breed, compatible with obtaining optimal quality products.

\section{Acknowledgements}

This study was supported by Spanish MCYT grant no. AGF990903. R. Barea was recipient of a FPI grant from the Spanish Ministry of Education and Science. We thank Mrs E. Colmenero and Mr F. Funes for skillful technical assistance and Sánchez Romero Carvajal Jabugo S.A. (Seville) and Sucesores de Miguel Vílchez Riquelme S.A. (Granada) for their helpful collaboration.

Part of present results were presented in Barea $R$, Nieto $R$ and Aguilera JF 2003. The effect of protein:energy ratio of the diet and feed intake on protein and energy metabolism of Iberian pigs growing from 50 to $100 \mathrm{~kg}$. Progress in research on energy and protein metabolism. EAAP publ. no. 109, pp. 121-124. Rostock-Warnemünde, Germany.

\section{References}

Agricultural Research Council 1981. The nutrient requirements of pigs. Commonwealth Agricultural Bureau, Slough.

Association of Official Analytical Chemists 1990. Official methods of analysis of the Association of Official Analytical Chemists, 15th edition. AOAC, Arlington, VA.

Barea R, Nieto R, Lara L, García MA, Vilchez MA and Aguilera JF 2006. Effects of dietary protein content and feeding level on carcass characteristics and organ weights of Iberian pigs growing between 50 and $100 \mathrm{~kg}$ body weight. Animal Science 82, 405-413.

Bikker P 1994. Protein and lipid accretion in body components of growing pigs: effects of body weight and nutrient intake, Ph.D. thesis, Wageningen Agricultural University, The Netherlands.

Black JL, Campbell RG, Williams IH, James KJ and Davies GT 1986. Simulation of energy and amino acid utilization in the pig. Research and Development in Agriculture 3, 121-145.

Campbell RG and Taverner MR 1988. Genotype and sex effects on the relationship between energy intake and protein deposition in growing pigs. Journal of Animal Science 66, 676-686.

Campbell RG, Taverner MR and Curic DM 1985. The influence of feeding level on the protein requirements of pigs between 20 and $45 \mathrm{~kg}$ liveweight. Animal Production 40, 489-496.

Cohen SA, Meys M and Tarvin TL 1989. The Pico-Tag method. A manual of advanced techniques for amino acid analysis. Millipore Corporation, Bedford, MA.

Fuller MF, Franklin MF, McWilliam R and Pennie K 1995. The responses of growing pigs, of different sex and genotype, to dietary energy and protein. Animal Science 60, 291-298.

Goering HK and Van Soest PJ 1970. Forage fiber analyses (apparatus, reagent, procedures and some applications). Agricultural Handbook no. 379. ARS-USDA, Washington, DC.

Kielanowski J 1965. Estimates of the energy cost of protein deposition in growing animals. In Energy metabolism. EAAP publication no. 11, pp. 13-20. Academic Press, New York.

Kyriazakis I and Emmans GC 1992. The effects of varying both energy and protein intake on the growth and body composition of pigs. II. The effects of varying both energy and protein intake. British Journal of Nutrition 68, 615-625. 
Möhn S and De Lange CFM 1998. The effect of body weight on the upper limit to protein deposition in a defined population of growing gilts. Journal of Animal Science 76, 124-133.

Moore S 1963. On the determination of cystine as cysteic acid. Journal of Biological Chemistry 238, 235-237.

National Research Council 1998. Nutrient requirements of swine, 10th revised edition. National Academy Press, Washington, DC.

Nieto R, Lara L, García MA, Gómez F, Zaldive M, Cruz M, Pariente JM, Moreno A and Aguilera JF 2001. Evaluación de un sistema integrado de alimentación en el cerdo ibérico. Análisis del consumo de alimentos e índices productivos. Sólo Cerdo Ibérico 6, 57-59.

Nieto R, Lara L, García MA, Vílchez MA and Aguilera JF 2003. Effects of dietary protein content and food intake on carcass characteristics and organ weights of growing lberian pigs. Animal Science 77, 47-56.

Nieto R, Miranda A, García MA and Aguilera JF 2002. The effect of dietary protein content and feeding level on the rate of protein deposition and energy utilization in growing Iberian pigs from 15 to $50 \mathrm{~kg}$ body weight. British Journal of Nutrition 88, 39-49.

Noblet J, Karege C, Dubois S and Van Milgen J 1999. Metabolic utilization of energy and maintenance requirements in growing pigs: effects of sex and genotype. Journal of Animal Science 77, 1208-1216.

Quiniou N, Dourmad JY and Noblet J 1996. Effect of energy intake on the performance of different types of pig from 45 to $100 \mathrm{~kg}$ body weight. 1. Protein and lipid deposition. Animal Science 63, 277-288.
Rao DS and McCracken KJ 1991. Effect of energy intake on protein and energy metabolism of boars of high genetic potential for lean growth. Animal Production 52, 499-507.

Rivera-Ferre MG, Aguilera JF and Nieto R 2005. Muscle fractional protein synthesis is higher in Iberian than in Landrace growing pigs fed adequate or lysine-deficient diets. Journal of Nutrition 135, 469-478.

Siebrits FK, Kemm EH, Ras MN and Barnes PM 1986. Protein deposition in pigs as influenced by sex, type and livemass. 1. The pattern and composition of protein deposition. South Africa Journal of Animal Science 16, 23-27.

Statistical Analysis Systems Institute 1990. User's guide. SAS Institute, Inc., Cary, NC.

Tauson AH, Chwalibog A, Jakobsen K and Thorbek G 1998. Pattern of protein retention in growing boars of different breeds, and estimation of maximum protein retention. Archives of Animal Nutrition 51, 253-262.

Thorbek G, Chwalibog A and Henckel S 1984. Nitrogen and energy metabolism in pigs of Danish Landrace from 20 to $120 \mathrm{~kg}$ live weight. Norm for protein and energy requirements for maintenance and growth. Report from National Institute of Animal Science, Copenhagen 563, 114.

Van Milgen J and Noblet J 1999. Energy partitioning in growing pigs: the use of a multivariate model as an alternative for the factorial analysis. Journal of Animal Science 77, 2154-2162.

Whittemore CT, Tullis JB and Emmans GC 1988. Protein growth in pigs. Animal Production 46, 437-445. 